\title{
A STUDY ON PHYTOPLANKTON DISTRIBUTION, ABUNDANCE AND COMMUNITY STRUCTURE IN FISH PONDS OF AL- ABBASSA FISH FARM IN RELATION TO PHYSICO-CHEMICAL PROPERTIES OF WATER
}

\author{
Amany A. Mohammed*, Entesar A. Ahmed**, Samir M. Saeed*, Aida \\ M. Dawah*, Rawheya A. Salah El Din** \\ * Limnology Department, Central Laboratory for Aquaculture Research, \\ Agricultural Research Center, Egypt. \\ **Botany and Microbiology Department, Faculty of Science, Al-Azhar University \\ (Girls Branch), Nasr City, Cairo, Egypt.
}

\begin{abstract}
:
This study aims to investigate the phytoplankton dynamics (distribution, composition) and their relation to water quality parameter in Ismailia canal and Abbassa fish farm (inlet, outlet and the fish ponds).The study was carried out from April, 2014 to May, 2015. Physical, chemical parameters and phytoplankton estimation were measured in situ and laboratory. The results showed that, the physico- chemical parameters of water were significantly varied among different seasons and the studied sites. Phytoplankton communities are represented by eight phyla namely; Chlorophyta, Cyanophyta, Euglenophyta, Bacillariophyta, Chrysophyta, Dinophyta, Cryptophyta and Xanthophyta. Their major number (22724 Org./ml) was detected at the fishponds (site C), while their minor number (9374 Org./ml) was detected at the main feeder (MF), (site A). Chlorophyceae was the predominant class at all studied sites except at (MF) where; Bacillariophyceae occupied the first predominant position. Results demonstrated that occurrence of 247 taxa of phytoplankton at (MF), 273 taxa at (inlet), 304 taxa at fishponds and 292 taxa at outlet. Also, Shannon and Weaver diversity index $\left(\mathrm{H}^{-}\right)$was studied and the results showed that the mean range of the phytoplankton diversity index $\left(\mathrm{H}^{-}\right)$was low $(<$ 2.0) at all the studied sites and this is indication of moderate pollution. It is concluded that, both seasonal variations and physico-chemical parameters of water have great impact on phytoplankton dynamics and its biological diversity.
\end{abstract}

Key words: Chlorophyll "a", diversity indices, fishponds, phytoplankton dynamics, water quality, water supply. 


\section{Introduction}

Phytoplankton organisms (composition and density) are affected by both physical and chemical characteristics of fish pond water which lead to changes in both aquatic environment and dynamics of fish ponds.

The artificial shallow systems, their productivity and profitability are highly determined by human activities (Lukaw et al., 2013). The interactions of both the physical and chemical properties of water play a significant role in composition, distribution, abundance, movements and diversity of aquatic organisms (Mustapha and Omotosho, 2005).

Managing successful aquaculture processes vary from pond to pond even under similar ecological conditions and in turn affect quality and quantity abundance of phytoplankton communities in fishponds (Bhuiyan $\boldsymbol{e t}$ al., 2008).

Study of planktonic diversity as biological indicator contributes to understanding of the environmental status of a water body (Rani and Sivakumar, 2012).

Most of the published references in Egypt are generally based on the relationship between fish production and composition of major phytoplankton groups (Mageed and Konsowa, 2002; Abdel-Tawwab et al., 2007; Saeed and Al-Nagaawy, 2013; Saeed and Batran, 2014). However, no investigations were carried out dealing with the impact of pond management (nutrient additions) and climatic conditions (all year around) on phytoplankton dynamic (abundance and composition), phytoplankton biomass and diversity in fish farms. So, the results have been generally poor understanding of the dynamics of phytoplankton in aquaculture ponds.

So, this study is carried out to investigate the impact of the physicochemical parameters on the species composition, structure and distribution of the phytoplankton community to give an understanding of the dynamics of phytoplankton in aquaculture ponds and help in maintaining water quality in fish farms to ensure optimal growth of fish and get non-polluted environment. 


\section{Materials and Methods}

\section{Study sites}

Water samples were collected from four sampling sites at Al-Abbassa fish farm (the World Fish Center) and Ismailia canal including four sites namely; 1Ismailia canal site A, which is the main feeder (MF) for the area and the fish farm; 2- the irrigation canal (Inlet), site B, which supplies fish ponds with mixed water (Nile and underground water); 3- the fish ponds (site C) which receive different inputs as feed and organic fertilizers and 4- the drainage canal (Outlet), site D, where water is discharged from the fish farm as shown in Figure (1).

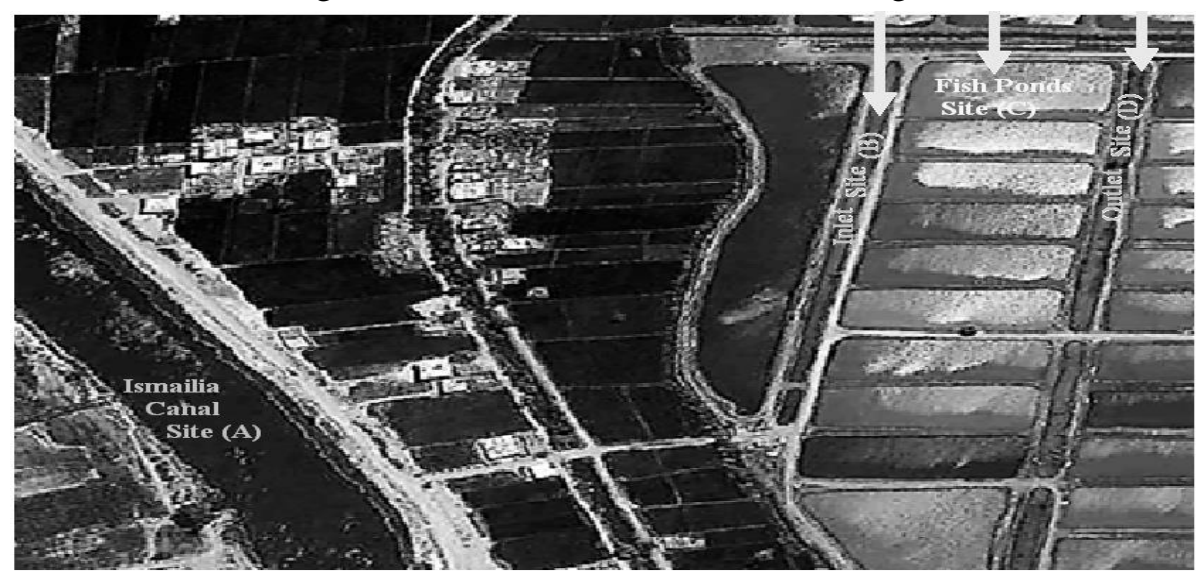

Figure (1): Map demonstrates the location of Al-Abbassa fish farm at the World Fish Center and Ismailia canal.

\section{Sampling and water analysis}

Water samples were taken monthly (from April, 2014 to May, 2015) at different sites to analyze physico-chemical properties and phytoplankton estimation. Water temperature and $\mathrm{pH}$ were measured directly at the sampling site by portable Multi-parameter (pH/EC/TDS/Salt), PCSTestr 35 (Singapore). Dissolved oxygen concentration was determined by modified Winkler method (APHA, 2005). Water transparency $(\mathrm{cm})$ was measured by using a Secchi Disc (SD) $30 \mathrm{~cm}$ in diameter crossed by white and black color. Water samples were taken with a water sampler constructed from a PVC pipe $(5-\mathrm{cm}$ diameter, $1.5-\mathrm{m}$ long) from at least five spots between $10.00 \mathrm{am}$ and $12.00 \mathrm{pm}$ at a depth of $30 \mathrm{~cm}$ below the water surface and mixed together in a plastic container according to Boyd and Tucker (1992). Then water samples were put in two plastic bottles, 
one liter each. One bottle is used for chemical analysis and the other preserved in a Lugol's solution at a ratio of $3.0 \mathrm{ml}$ Lugol's solution to $1000 \mathrm{ml}$ sample for quantitative and qualitative analysis of phytoplankton.

The concentration $(\mathrm{mg} / \mathrm{l})$ of alkalinity (carbonate and bicarbonate as $\left.\mathrm{CaCO}_{3}\right)$, total ammonia $\left(\mathrm{NH}_{4}{ }^{+}-\mathrm{N}+\mathrm{NH}_{3}-\mathrm{N}\right)$, nitrite $\left(\mathrm{NO}_{2}-\mathrm{N}\right)$, nitrate $\left(\mathrm{NO}_{3}-\mathrm{N}\right)$, orthophosphate $\left(\mathrm{PO}_{4}-\mathrm{P}\right)$ and chlorophyll"a" content $(\mu \mathrm{g} / \mathrm{l})$ were measured by the methods described by Boyd and Tucker (1992).

Phytoplankton were identified up to the species level according to the key of freshwater algae (Prescott, 1970). The population density was expressed as (Org./ml).Three indices were used to estimate the community structure; diversity; Shannon and Weaver diversity index $\left(\mathrm{H}^{-}\right)$and Simpson's Reciprocal Index as well as evenness or equitability (Pielou, 1975).

\section{Statistical analysis}

Statistical analysis was performed using the analysis of variance (ANOVA) and Duncan's Multiple Range Test to determine differences between spatial and seasonal means at significance level of $\mathrm{p}<0.05$. Standard errors were also estimated (Dytham, 1999).

\section{Results and Discussion}

The seasonal variations of water quality parameters at different sites are illustrated in Figures (2- 8). The fluctuations in temperature, $\mathrm{pH}$ and dissolved oxygen at different studied sites are presented in Figure (2 A, B and C). Temperature was not significantly different among different sites, where it ranged between $17.5^{\circ} \mathrm{C}$ (in winter) at site $\mathrm{A}$ and $30.3^{\circ} \mathrm{C}$ (in summer) at site $\mathrm{D}$. Temperature is one of the most important and essential parameter of aquatic habitats because almost it controls all the physical, chemical and biological properties (Fig. 2A). A temperature of about $35^{\circ} \mathrm{C}$ is generally considered as threshold for survival of aquatic life (ICAR, 2011). 

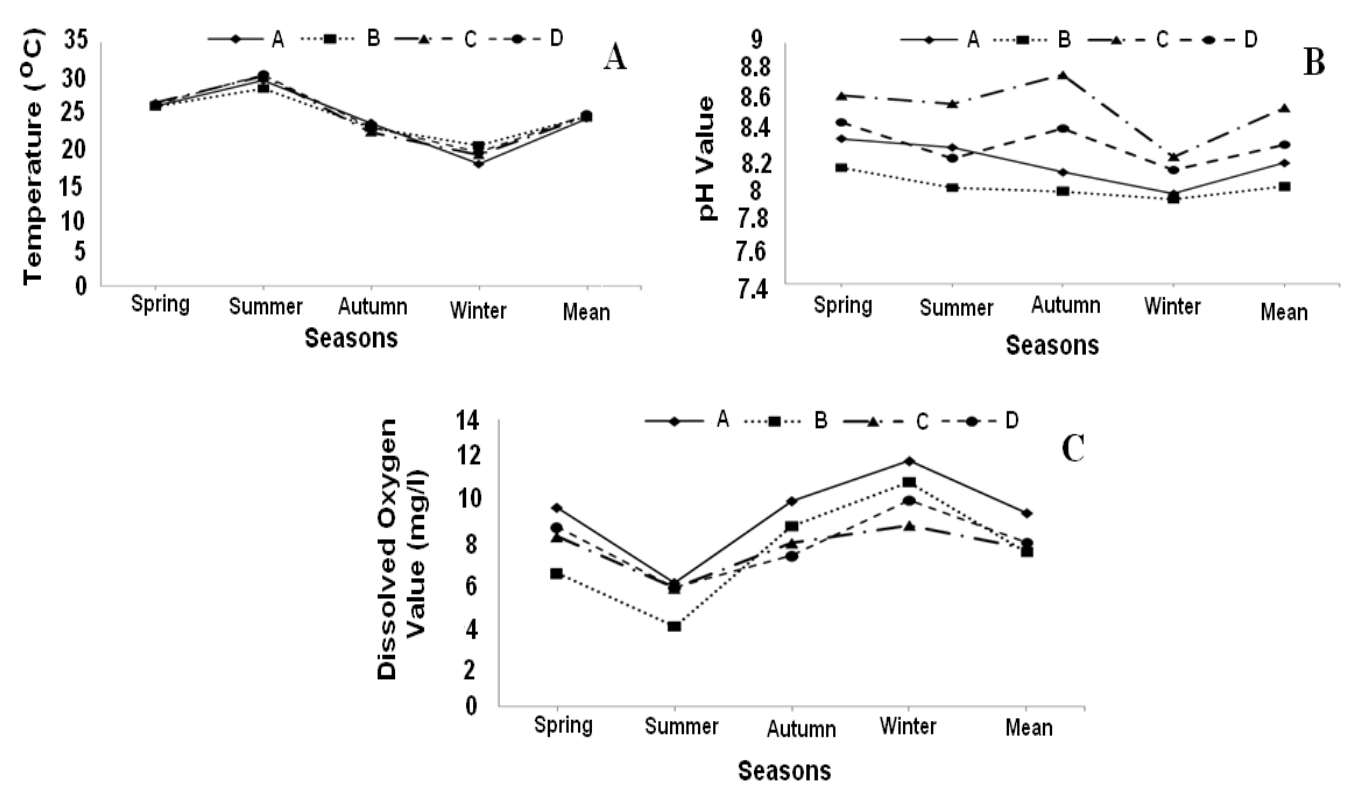

Figure (2): Seasonal variations of A- temperature $\left({ }^{\circ} \mathrm{C}\right), \mathrm{B}-\mathrm{pH}$ and $\mathrm{C}$-dissolved oxygen (DO) at the studied sites.

The $\mathrm{pH}$ recorded for all sites was in the alkaline side (Fig. 2B). Values of $\mathrm{pH}$ fluctuated between 7.9 in winter at sites (A and B) and 8.78in (autumn) at site (C), while the total annual means were $8.2,8.04,8.56$ and 8.32 at sites A, B, C and $\mathrm{D}$, respectively. These findings may be corresponding to phytoplankton count, where the highest total count was observed during autumn season and the lowest one was detected during winter season. High $\mathrm{pH}$ may be resulted from high photosynthetic activity of phytoplankton and other aquatic plants causing decrease in the levels of free carbon dioxide (Shiddamallayya and Pratima, 2008). Also, Boyd (1998) stated that decrease in $\mathrm{pH}$ level is due to excessive respiration of microorganisms as well as fish excretion, while photosynthesis increases $\mathrm{pH}$. The seasonal variations in $\mathrm{pH}$ were mainly affected by temperature, carbonate and bicarbonate system and the photosynthetic activity of the primary producers (Abdo, 2005).

It is observed that dissolved oxygen is inversely proportional to temperature, where it ranged between $(3.9 \mathrm{mg} / \mathrm{l})$ at site $\mathrm{B}$ in summer and (11.9 $\mathrm{mg} / \mathrm{l})$ at site $\mathrm{A}$ in winter, while the total means were $9.44,7.53,7.72$ and $8.0 \mathrm{mg} / \mathrm{l}$ 
at sites A, B, C and D, respectively, (Fig. 2C). These results are in agreement with Niusha et al. (2014). They mentioned that dissolved oxygen was high at all sites during the winter season. They refer it due to the cumulative effect of heavy rainfall and higher wind velocity which is good condition to produce freshwater mixing. On the other hand, relatively lower values were observed during summer and this may be due to the increased surface water temperature, which reduces the dissolution of $\mathrm{O}_{2}$ in the surface waters (Viijayakumar et al., 2000).

Figure (3 A, B and C) shows the fluctuations in transparency (SD), total alkalinity and total dissolved solids. Seasonally, Secchi Disc (SD) readings ranged between $(12.4 \mathrm{~cm})$ in autumn at site D and $(94.4 \mathrm{~cm})$ in winter at site A. The decrease in SD (14.6-15.6 cm) at site C (Fish ponds) is mainly caused by the abundance of phytoplankton populations and suspended matter (clay and organic materials) that result from sediment turbulence by fish (Fig. 3 A). Perhaps, the transparency was lower in the autumn season at sites (B, C and D) due to high planktonic population. The maximum transparency recorded in Ismailia canal (site A) may be attributed to the increase of water level in the canal. The annual averages of SD readings showed that there are significant differences $(\mathrm{P}<0.05)$ among the studied sites, where the total means were $88.9,20.1,15.3$ and $13.8 \mathrm{~cm}$ at sites A, B, C and D, respectively. The important of transparency is to point out the absence or presence of food materials as well as the productivity of the water body that effect by suspended particles such as silt or microorganisms our results were in accordance with the results found by (Ferdoushi et al., 2008; SipaúbaTavares et al., 2011).

Alkalinity in most natural water is the function of bicarbonate and carbonates. It is also used as a measure of productivity (Hulyal and Kaliwal, 2011). Seasonally; there are significant differences among different seasons, where total alkalinity fluctuated between $159.8 \mathrm{mg} / \mathrm{l}$ at site $\mathrm{A}$ in summer and $265.7 \mathrm{mg} / \mathrm{l}$ at site D in autumn (Fig. 3 B).

The annual mean values of total alkalinity demonstrated that there are significant differences among the studied sites, where the highest values were recorded at sites $\mathrm{C}$ and $\mathrm{D}$, while the lowest values were detected at sites $\mathrm{A}$ and $\mathrm{B}$. Saeed and Batran (2014) mentioned that higher total alkalinity values in polyculture ponds might be due to the high rate of $\mathrm{CO}_{2}$ production resulted from the decomposition of increased organic material released from sediment as well as fish excretion. Boyd (1998) mentioned that the changes of alkalinity were 
influenced by climatic factors such as temperature as well as fish culture practices such as fertilization.

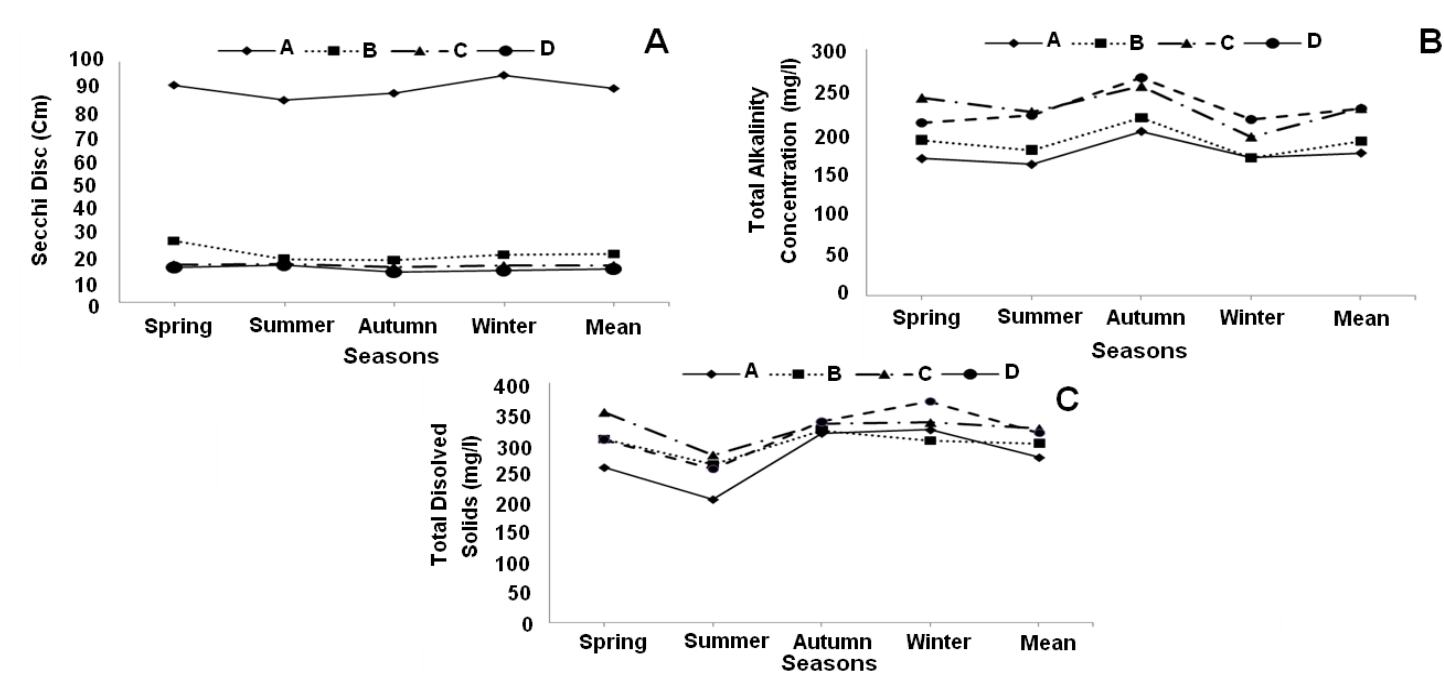

Figure (3): Seasonal variations of A-transparency (SD), B-total alkalinity and C-total dissolved solids at the studied sites

Seasonally, the results of total dissolved solids showed significant differences $(\mathrm{P}<0.05)$ among seasons, where the values ranged between $205.7 \mathrm{mg} / \mathrm{l}$ at site A during summer and $369.2 \mathrm{mg} / \mathrm{l}$ at site $\mathrm{D}$ during winter. The annual averages of total dissolved solids showed that there are no significant differences among the studied sites. The TDS of a freshwater pond should be in the range of $50-2000 \mathrm{mg} / \mathrm{l}$ for optimum fish production (Boyd, 1998).

Figure (4 A) shows the fluctuations in total ammonia. Ammonia is introduced into the pond through dead phytoplankton, uneaten feeds, dead and decaying organic matter. Seasonally, there are significant differences among seasons. The annual averages of total ammonia follow the order: $\mathrm{C}>\mathrm{D}>\mathrm{B}>\mathrm{A}$. Low ammonia concentration at site $\mathrm{C}$ during September associated with the cyclic feeding regimes (periods of feed deprivation) (Turano et al., 2008).

Meanwhile, the results showed significant differences among seasons when concerning to the nitrite. The values of nitrite ranged between $0.014 \mathrm{mg} / \mathrm{l}$ at sites $\mathrm{A}$ and $\mathrm{B}$ during spring and $0.11 \mathrm{mg} / \mathrm{l}$ at site $\mathrm{C}$ during autumn as shown in Fig. (4 
B). Boyd (1998) recommended nitrite concentration in aquaculture pond water should not exceed $0.3 \mathrm{mg} / \mathrm{l}$.

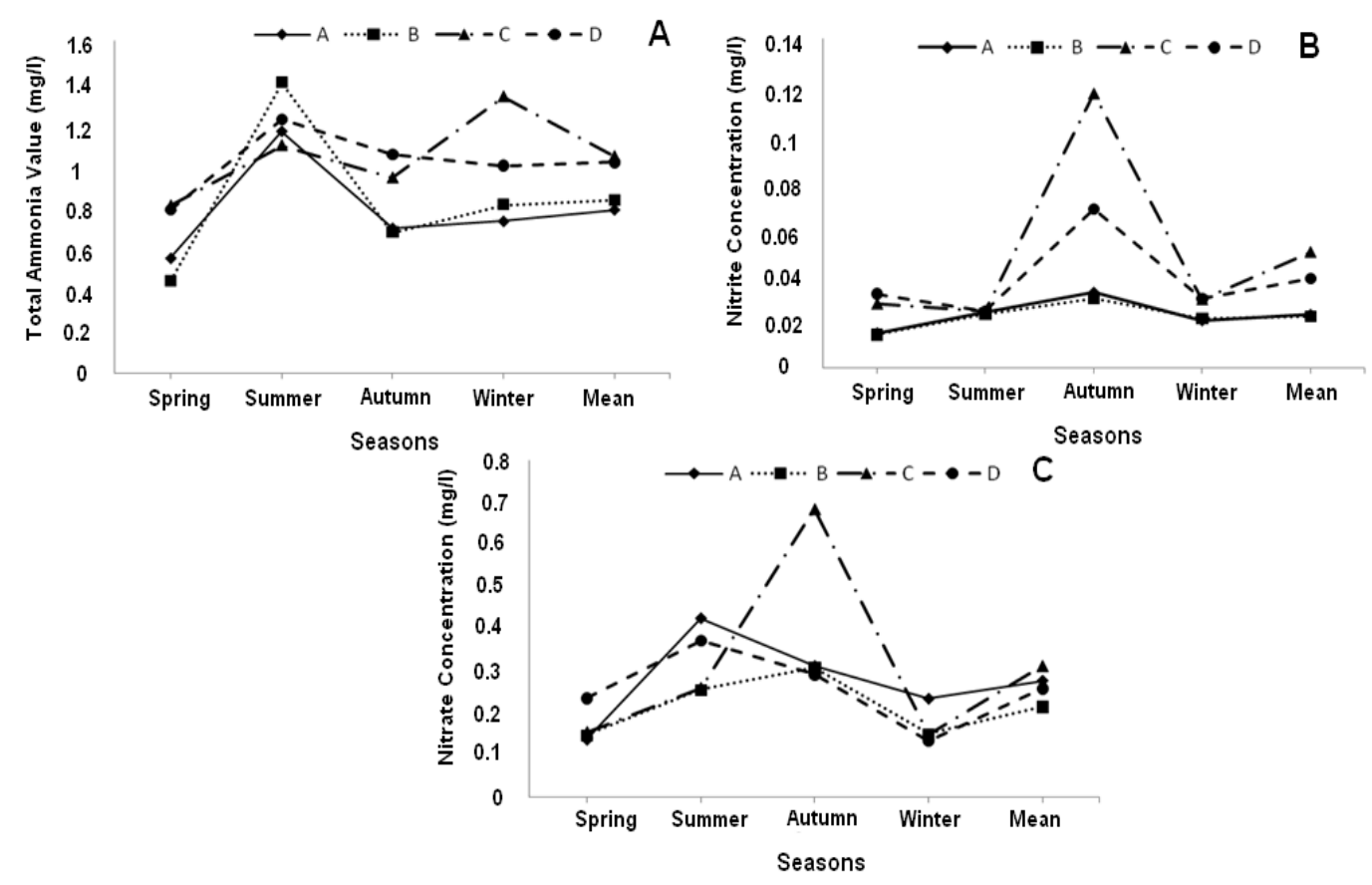

Figure (4): Seasonal variations of: A- total ammonia, B- nitrite and C- nitrate at the studied sites.

The values of nitrate ranged between $0.13 \mathrm{mg} / \mathrm{l}$ at sites (A during spring and $\mathrm{D}$ during winter) and $(0.68 \mathrm{mg} / \mathrm{l})$ at site $\mathrm{C}$ during autumn. There is a positive correlation between nitrate and phytoplankton abundance in this study and this agrees with the finding of Nassar and Shams El-Din (2006). In the present investigation it was observed that at site A (MF) the high density of diatoms coincides with high nitrate concentrations while diatoms reached its minimum density at spring season. These finding agree with Sipaúba-Tavares et al. (2011) who speculated that alkaline $\mathrm{pH}$ (between 7.2 and 8.8) and high nitrate concentrations supported a high population of diatoms. The annual means of 
nitrate were $0.27,0.21,0.31$ and $0.25 \mathrm{mg} / \mathrm{l}$ at sites $\mathrm{A}, \mathrm{B}, \mathrm{C}$ and $\mathrm{D}$, respectively, as shown in Fig. (4 C).

Figure (5) show the fluctuations in orthophosphate. Seasonally, orthophosphate ranged between $0.03 \mathrm{mg} / \mathrm{l}$ at site A during winter and $0.14 \mathrm{mg} / \mathrm{l}$ at site $\mathrm{C}$ during summer. These findings are in agreement with Yadav et al. (2013) who stated that phosphate concentration in fishponds was more in summer followed by a decline in winter season. Higher phosphate content during summer is due to high temperature (Patil et al., 2013). $\mathrm{PO}_{4}-\mathrm{P}$ levels recorded at fishponds showed a remarkable increase compared to the main feeder (Site A) and this may be related to different inputs as feed and organic fertilizers in fishponds as well as fish feces. Also, Stickney et al. (1979) stated that a large proportion of phosphorus in the feces is orthophosphate. The annual averages of orthophosphate were $0.04,0.07,0.10$ and $0.09 \mathrm{mg} / \mathrm{l}$ at site $\mathrm{A}, \mathrm{B}, \mathrm{C}$ and $\mathrm{D}$, respectively.

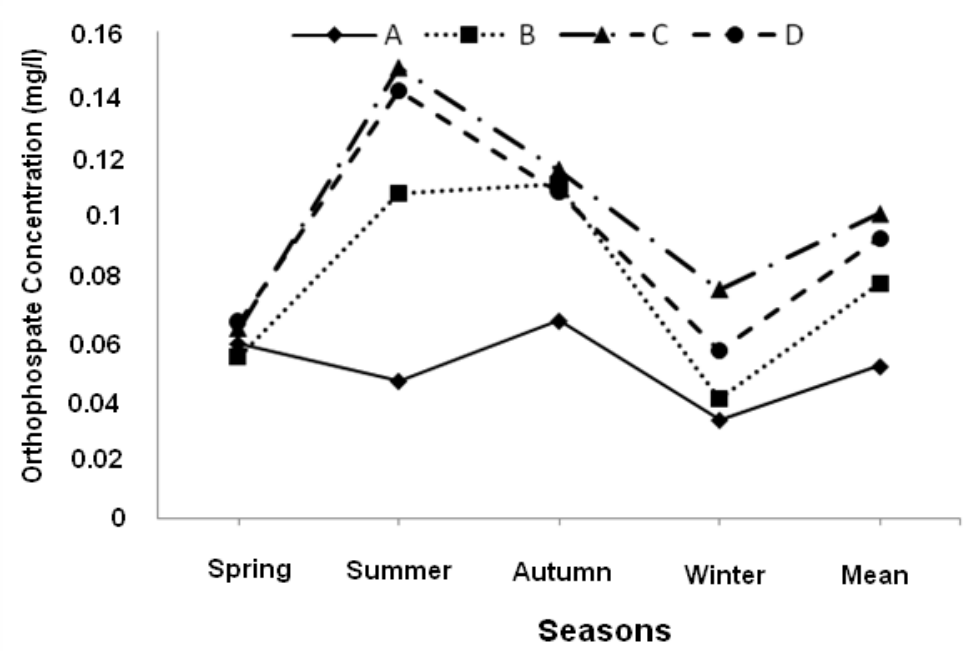

Figure (5): Seasonal variations of orthophosphate at the studied sites

Figure (6) clarified the fluctuations in chlorophyll "a" content. Seasonally, data showed that there are significant differences among different seasons, where chlorophyll "a" contents ranged between $20.9 \mu \mathrm{g} / \mathrm{l}$ at site B during winter and $311.06 \mu \mathrm{g} / \mathrm{l}$ at site $\mathrm{C}$ during autumn. 
It was observed that the maximum concentration of chlorophyll "a" at sites (B, C and D) was detected during autumn season while, the minimum concentration was recorded during winter season. These results correlated with total phytoplankton count, where Chlorophyceae was the most dominant class. Chlorophyll "a" and phytoplankton follow the following order: autumn > summer $>$ spring > winter. It is thought that the chlorophyll content is 4-6 times in green algae higher than that in Cyanophyta and Bacillariophyta. A predominance of Chlorophyta in phytoplankton is responsible for high relative content of chlorophyll "a" in the total biomass of phytoplankton (Mineyeva, 2004).

On the other hand, at site A (MF) chlorophyll "a" didn't correlate with phytoplankton abundance, where chlorophyll "a" follows the following order: autumn > summer > winter> spring, while phytoplankton count follows the following order: winter $>$ autumn $>$ summer $>$ spring. These results are supported by Primmer (2010) who detected that samples containing the highest chlorophyll "a" concentration and phytoplankton count were not strongly correlated. This demonstrates that chlorophyll "a" concentration and phytoplankton abundance may not always be directly related.

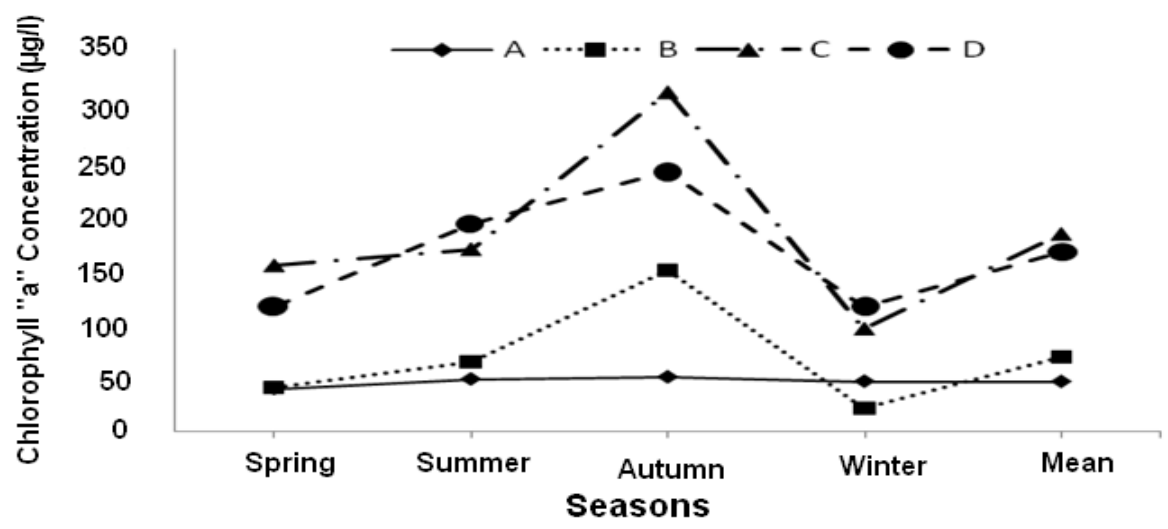

Figure (6): Seasonal variations of Chlorophyll "a" at the studied sites.

The annual averages of chlorophyll "a" concentrations showed that there are significant differences $(\mathrm{P}<0.05)$ among the studied sites, where the highest values were observed at sites $C$ and $D$, while the lowest values were recorded at sites A and B. El-Otify (2015) stated that phytoplankton biomass in terms of chlorophyll "a" concentrations were always of relatively higher values in the fish Egyptian J. of Phycol. Vol. 18, 2017 - 30 - 
pond than its water supply thus, chlorophyll- $a$ concentrations appeared to be promoted by sufficient nutrients.

\section{Phytoplankton}

The present study revealed that the algal communities belonged to Chlorophyta, Cyanophyta, Euglenophyta, Bacillariophyta, Chrysophyta, Dinophyta, Cryptophyta and Xanthophyta. As shown in Table (1) Chlorophyceae individuals achieved the first order of abundance at all sites except at site A, where Bacillariophyceae occupy the first order of distribution during most of the study period.

It was observed that, site A (MF) was represented by 247 taxa and takes the following order: Bacillariophyta> Chlorophyta> Cyanophyta> Euglenophyta> Cryptophyta $>$ Dinophyta $>$ Chrysophyta $>$ Xanthophyta as shown in Table (1). The most abundant species belonged to Bacillariophyta were Synedra ulna, Cyclotella ocellata, Surirella ovate and Aulacoseira ganulata. Also, Tetrastrum triangulare, Actinastrum hantzschii, Scenedesmus ecornis and Tetradron minimum were the most abundant species belonged to Chlorophyta. The most abundant species of Cyanophyta were Merismopedia minima, Merismopedia convolute and Merismopedia ferrophila. Besides, Euglena geniculata, Eutreptia viridis and Euglena obtuse were the most abundant species belonged to Euglenophyta. At site A, Bacillariophyceae reached maximum ratio $(46.4 \%)$ in winter and minimum one (44\%) in spring from the total population. The dominance of diatoms might be attributed to the recognized occurrence of iron and silicon in Nile water (Shehata et al., 2009; Shehata and Badr, 2010).

Chlorophyceae reached its maximum ratio $(49.4 \%)$ in spring and minimum ratio $(3.6 \%)$ in winter from the total population, while Cyanophyceae reached its maximum density (19.6\%) during summer. These results agree with Shehata et al. (2009) who mentioned that the increase in total phytoplankton number in Nile water mainly attributed to diatoms which represents $75-97.8 \%$ of total algal counts and dominated by centric form and secondarily by pinnate form while, green algae restricted their growth to the spring season and comprise about $20 \%$ of total algal counts. They also mentioned that blue-green algae had its maximum density in summer season constituting $8 \%$ of total algal counts.

Site B (Inlet) represented by 273taxa and follow the following order: Chlorophyta> Bacillariophyta> Cyanophyta> Euglenophyta> Cryptophyta> Chrysophyta> Dinophyta> Xanthophyta as shown in Table (1). The most abundant spesies belonged to Chlorophyta were: Scenedesmus ellipsoidus, 
Closterium pronum, Scenedesmus communis and Lagerheimia ciliata. In addition, the most abundant species belonged to Bacillariophyta were Pinnularia viridis, Cyclindrotheca closterium, Nitzschi apalea and Cyclotella ocellata. Besides, Merismopedia convoluta, Merismopedia ferrophila, and Cylidrospermopsis curvispora were the most abundant species belonged to Cyanophyta. Also, Euglena acus, Euglena oxyuris and Distigma gracile were the most abundant species belonged to Euglenophyta.

Fishponds (Site C) represented by 304 taxa which take the following order: Chlorophyta> Bacillariophyta> Euglenophyta> Cyanophyta> Cryptophyta> Dinophyta $>$ Xanthophyta $>$ Chrysophytaas shown in Table (1). The most abundant species belonged to Chlorophyta were Closterium pronum, Palmellococcus miniatus and Scenedesmus ecornis. Also, Cyclotella meneghiniana, Nitzschia rostellata and Navicula decusis were the most abundant species belonged to Bacillariophyta. In addition, Euglena oxyuris, Euglena gracilis, Phacus suecius and Euglena sanguinea were the most abundant species belonged to Euglenophyta. Besides, Cylidrospermopsis raciborskii, Cylidrospermopsis curvispora and Merismopedia tenuissima were the most abundant species belonged to Cyanophyta.

Site D (Outlet) represented by 292 taxa and follow the order of: Chlorophyta> Euglenophyta> Bacillariophyta> Cyanophyta> Cryptophyta> Dinophyta> Chrysophyta> Xanthophyta as shown in Table (1). The most abundant species belonged to Chlorophyta were Closterium pronum, Kirchneriella contorta and Palmellococcus miniatus. Also, Strombomonas fluviatilis, Euglena oxyuris and Euglena acus were the most dominant species belonged to Euglenophyta. The most abundant species belonged to Bacillariophyta were Aulacoseira Sp, Nitzschia palea and Cyclotella meneghiniana. Besides, Merismopedia minima and Anabaena variabilis were the most abundant species belonged to Cyanophyta.

Saeed and Batran (2014) studied phytoplankton composition in polyculture ponds (Nile tilapia with catfish) and found that Chlorophyceae occupy the first order of abundance followed by Bacillariophyceae then Cyanophyceae and Euglenophyceae. Hossain et al. (2013) stated that Chlorophyceae dominated the phytoplankton groups, followed by Bacillariophyceae. This may be attributed to high temperature and other favorable water quality parameters as well as high levels of total alkalinity. The dominance of Chlorophyceae and Bacillariophyceae 
at the expense of Cyanophyceae and Euglenophyceae may be as a result of decrease in dissolved iron $\mathrm{Fe}^{+2}$ (Khan and Bhat, 2000).

Table (1): Annual means of phytoplankton divisions and species numbers (Org./ml) at the studied sites.

\begin{tabular}{|c|c|c|c|c|c|c|c|c|}
\hline \multirow{2}{*}{$\begin{array}{c}\text { Site } \\
\text { Division }\end{array}$} & \multicolumn{2}{|c|}{$\begin{array}{c}\text { Site A } \\
\text { (Main feeder) }\end{array}$} & \multicolumn{2}{|c|}{$\begin{array}{l}\text { Site B } \\
\text { (Inlet) }\end{array}$} & \multicolumn{2}{|c|}{$\begin{array}{c}\text { Site C } \\
\text { (Fish ponds) } \\
\end{array}$} & \multicolumn{2}{|c|}{$\begin{array}{c}\text { Site D } \\
\text { (Outlet) } \\
\end{array}$} \\
\hline & $\begin{array}{l}\text { Algae } \\
\text { count }\end{array}$ & $\begin{array}{c}\text { Species } \\
\text { number }\end{array}$ & $\begin{array}{l}\text { Algae } \\
\text { count }\end{array}$ & $\begin{array}{c}\text { Species } \\
\text { number }\end{array}$ & $\begin{array}{l}\text { Algae } \\
\text { count }\end{array}$ & $\begin{array}{c}\text { Species } \\
\text { number }\end{array}$ & $\begin{array}{l}\text { Algae } \\
\text { count }\end{array}$ & $\begin{array}{c}\text { Species } \\
\text { number }\end{array}$ \\
\hline Chlorophyceae & 3665 & 106 & 4755 & 91 & 10734 & 108 & 6992 & 109 \\
\hline Cyanophyceae & 1276 & 23 & 1285 & 31 & 2171 & 29 & 2244 & 24 \\
\hline Euglenophyceae & 327 & 28 & 574 & 36 & 4647 & 67 & 4377 & 70 \\
\hline Bacillariophyceae & 4064 & 86 & 3367 & 108 & 4700 & 90 & 3665 & 81 \\
\hline Chrysophyceae & 7 & 1 & 39 & 2 & $\mathbf{0}$ & $\mathbf{0}$ & 8 & 1 \\
\hline Dinophyceae & 14 & 2 & 12 & 2 & 88 & 5 & 47 & 3 \\
\hline Cryptophyceae & 19 & 1 & 90 & 3 & 367 & 4 & 203 & 4 \\
\hline Xanthophyceae & $\mathbf{0}$ & $\mathbf{0}$ & $\mathbf{0}$ & $\mathbf{0}$ & 17 & 1 & $\mathbf{0}$ & $\mathbf{0}$ \\
\hline Total & 9374 & 247 & 10122 & 273 & 22724 & 304 & 17536 & 292 \\
\hline
\end{tabular}

Gledhill and Van den Berg (1994) have shown that about $99.0 \%$ of the dissolved iron in surface water is organically bound and that the concentrations of organic iron chelators far exceed the concentration of dissolved iron. Both laboratory and field studies has linked the availability of $\mathrm{Fe}$ to $\mathrm{N}_{2}$-fixation in cyanobacteria (Paerl et al., 1994) as iron deficiency causes a decrease in heterocyst formation in the nitrogen-fixing freshwater cyanobacterium Anabaena catenula. Since iron is a key component of chromophore synthesis (Straus, 1994), most photoautotrophs, including cyanobacteria, are highly vulnerable to iron deficiency. Also, De Wever et al. (2008) stated that Chlorophytes and diatoms appeared to be stimulated by $\mathrm{N}$ and $\mathrm{P}$ rather than by $\mathrm{Fe}$ in contrast to cyanobacteria and Euglenophyta.

Euglenophyceae showed maximum count (8304 Org./ml) during autumn at site C (Fish Ponds), 8037 Org./ml at site D (Outlet), 865 Org./ml at site B (Inlet) and $674 \mathrm{Org} . / \mathrm{ml}$ at site A (Ismailia canal). This result agrees with Affan $\boldsymbol{e t}$ al. (2005) who stated that Euglenophytes showed their higher proportion in late autumn. They explained their finding by presence of some factors like, moderate temperature and accumulation of organic loads from surface run-off and clear 
sun-shine. Sen and Sonmez (2006) stated that Euglenophyceae increase synchronize with high total phosphorus, orthophosphate concentrations and high $\mathrm{pH}$ levels, as well as high levels of organic matter. Seasonally, as shown in Figure (7), the highest (42183 Org./ml) and the lowest (3301 Org./ml) total phytoplankton counts were obtained in autumn and winter at site $\mathrm{C}$ and $\mathrm{B}$, respectively.

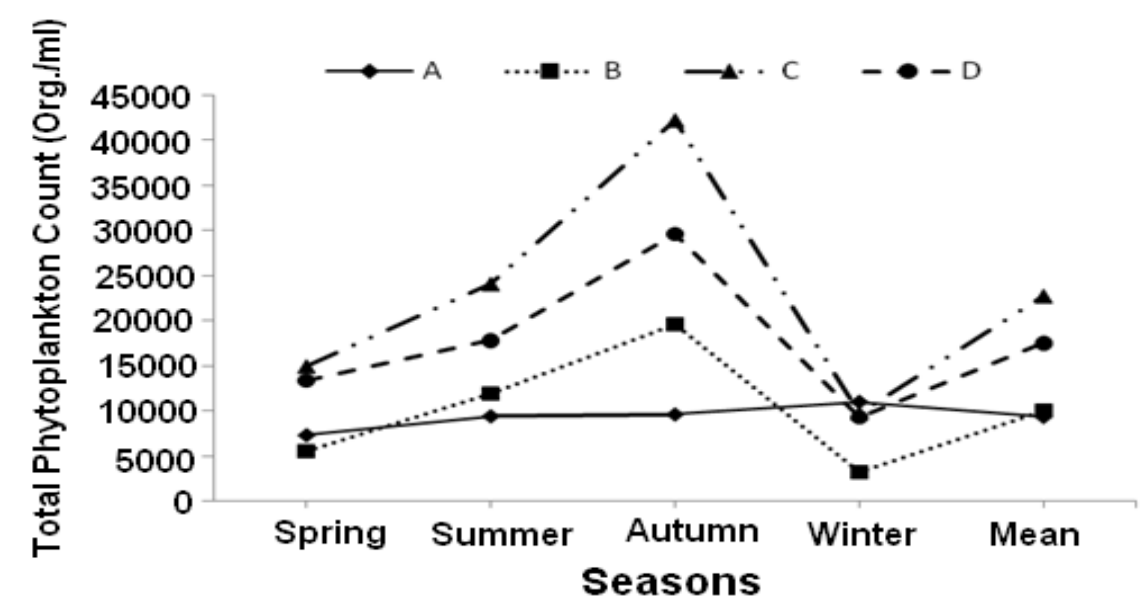

Figure (7): Seasonal variations of total phytoplankton (Org. /ml).

The locations ordered according to their annual mean of total phytoplankton count as follows: $\mathrm{C}>\mathrm{D}>\mathrm{B}>\mathrm{A}$, with the values 22724, 17536, 10122and 9374 Org./ml, respectively and represent $38 \%, 29 \%, 17 \%$ and $16 \%$ at site C, D, B and A respectively as shown in Table (1), Figure (7) and Figure (8). Increase of phytoplankton biomass in fishponds may result from the increase of re-suspension of sediments by fish as well as fish excretion which lead to release more nutrients that increase phytoplankton and water productivity (Garcia et al., 2012).

Adamovich and Zhukova (2014) showed that in fish ponds, the intensity of phytoplankton development was essentially higher than that in the Smerdiya River (the main source of its water supply) and this agrees with our results. Veronica et al. (2014) mentioned that high phytoplankton abundance in the pond could result from good range of total phosphate concentration in the pond 
promoting the phytoplankton growth, while limited phytoplankton abundance in the river is due to river current and current velocity dependence.

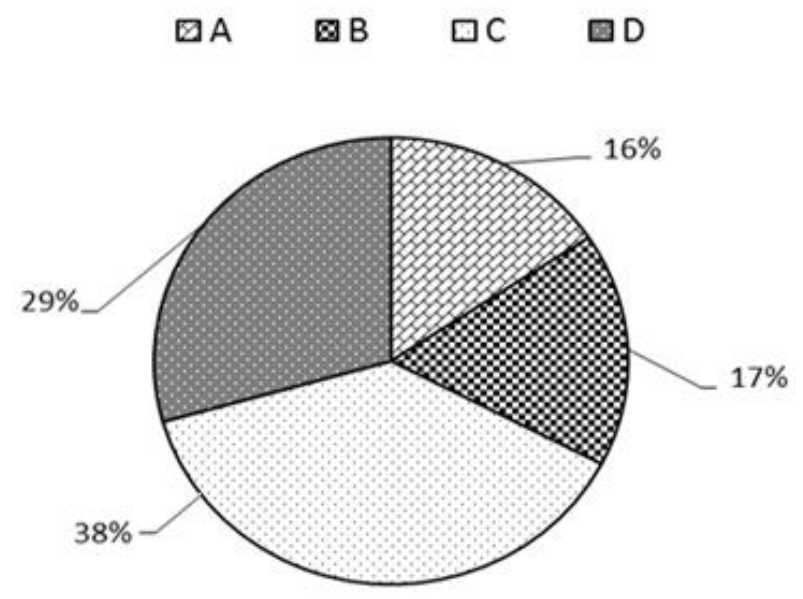

Figure (8): Annual mean of phytoplankton abundance as percentage (\%) in water at the whole studied sites.

Affan et al. (2005) mentioned that phytoplankton abundance was appeared to decrease gradually in the winter; this may be related with lower temperature, shorter day length, low $\mathrm{pH}$ and low concentration of nutrients. These findings are in agreement with our finding, since the lowest count of phytoplankton was observed during winter season at sites $\mathrm{B}, \mathrm{C}$ and $\mathrm{D}$.

\section{Biodiversity indices:}

The biological diversity was measured by three biodiversity indices namely; Shannon and Weaver diversity index $\left(\mathrm{H}^{-}\right)$and Simpson's Reciprocal Index as well as evenness or equitability. They are related to each other and showed which environment more diverse than the other. Shannon's index $\left(\mathrm{H}^{-}\right)$ encompasses species richness and species evenness components as overall index 
of diversity. Diversity is dependent on key ecological processes such as competition, predation, and succession. Therefore changes in these processes can alter the species diversity index through changes in evenness (Stirling and Wilsey, 2001). A community dominated by one or two species is considered to be less diverse than one in which several different species have a similar abundance. Seasonally, the values ranged between 0.9 at site A during spring and 1.33 at site B during winter. The annual averages of phytoplankton diversity index $\left(\mathrm{H}^{-}\right)$were $1.02,1.13,1.251$ and 1.258 at sites A, B, C and D, respectively, as shown in Table (2). The higher values of Shannon's Index $\left(\mathrm{H}^{-}\right)$indicated the greater species diversity. A scientist concluded that the normal values range from 0-4.

Typical values are generally between 1.5 and 3.5 in most ecological studies, and the index is rarely greater than 4 .The present study revealed that mean range of phytoplankton diversity index $\left(\mathrm{H}^{-}\right)$in the studied sites was low (< 2.0). These findings coincide with Veronica et al. (2014) who found that the mean range of the phytoplankton diversity index $\left(\mathrm{H}^{-}\right)$in the river and ponds was low $(<2.3)$. However, a low species diversity index showed that there is domination by a few species in the area (Margalef, 1978), which is evident in the present investigation that several species were present but at the same time dominated by a small number of species. The lower the $\mathrm{H}^{-}$value the lower the phytoplankton diversity, and this condition may highly influence the water stability and living environment. It will easily change with relatively small environmental influence.

Table (2): Range and mean of Shannon and Weaver diversity, evenness of species, and Simpson's Reciprocal index at the studied sites.

\begin{tabular}{|c|c|c|c|c|}
\hline Parameter & Site A & Site B & Site C & Site D \\
& (Main feeder) & (Inlet) & (Fish ponds) & (Outlet) \\
\hline $\begin{array}{c}\text { Shannon and Weaver } \\
\left(\mathbf{H}^{-}\right)\end{array}$ & $\mathbf{0 . 9 - 1 . 1}$ & $\mathbf{0 . 9 1 - 1 . 3 3}$ & $\mathbf{1 . 0 7 - 1 . 3 2}$ & $\mathbf{1 . 1 7 - 1 . 2 9}$ \\
\hline $\begin{array}{c}\text { Simpson's Reciprocal } \\
\text { Index }\end{array}$ & $(1.02)$ & $(1.13)$ & $(1.251)$ & $(1.258)$ \\
\hline (1/D) & $(2.2-2.7$ & $2.16-3.22$ & $2.69-3.37$ & $2.92-3.34$ \\
\hline $\begin{array}{c}\text { Species Evenness } \\
(\text { E) }\end{array}$ & $\mathbf{0 . 1 - 0 . 2}$ & $\mathbf{0 . 1 - 0 . 1 7}$ & $\mathbf{0 . 1 - 0 . 1 4}$ & $\mathbf{0 . 1 2 - 0 . 1 3}$ \\
\hline
\end{tabular}


So, the diversity changed from site to another in the following order: site D $<\mathrm{C}<\mathrm{B}<\mathrm{A}$. Phytoplankton population in nutrient rich waters is more diverse than those in nutrient deficient waters Margalef (1964).

The species diversity index can serve as an indicator that the ecosystem is under the influence of pollution stress or eutrophication Telesh (2004). Lower species Shannon-Wiener diversity Index values indicated that the water body is under the influence of pollution. An increasing in diversity values means that the water quality is recovered.

Shannon- Weiner diversity index ranged from 1.02 to 1.258 showed that the studied sites have moderate pollution level. So, phytoplankton study is very important because it acts as primary producers and an efficient bio-indicator for water quality. El Sheekh et al. (2010) studied the water quality of river Nile at different locations and found it moderately polluted on the basis of biological assessment through diversity and sapropic indices that were less than three throughout the study period.

\section{Simpson's Reciprocal Index:}

The Simpson's Reciprocal Index is often used to quantify the biodiversity of habitats. It takes into account the number of species present as well as the abundance of species. The annual averages of Simpson's Reciprocal Index were $2.53,2.7,3.05$ and 3.16 at sites A, B, C and D respectively. Seasonally, the values ranged between 2.16 at site $\mathrm{B}$ during spring and (3.16) at site D during winter as shown in Table (2). The higher the value, is the greater the diversity. It was observed from this index that, the studied sites follow the following order: site D $<\mathrm{C}<\mathrm{B}<\mathrm{A}$.

\section{Evenness:}

The evenness index is a measure of the evenness with which individuals are divided among the taxa present. The values ranged between $0-1$. The closer the value to 1 the more even is the distribution of phytoplankton. Pirzan and PongMasak (2008) reported that if evenness index approaches to zero, the species evenness in the community is low and inversely if the evenness index approaches to 1 the species evenness in the community is the same. The annual averages of evenness index (E) were $0.14,0.12,0.12$ and 0.12 at sites $\mathrm{A}, \mathrm{B}, \mathrm{C}$ and $\mathrm{D}$, 
respectively, as shown in Table (2). From the annual average, it was observed that the entire evenness index values approach to zero, so the species evenness at all sites is low. It indicates that there are few species dominating the studied sites.

\section{Conclusion}

From this study, it can be concluded that phytoplankton composition and abundance are varied at the studied sites. No single factor is responsible for this variability. However, temperature, transparency, water $\mathrm{pH}$, seasonal variations, nutrient enrichment may be responsible for the variable changes in the phytoplankton distribution, composition and their abundance. The present study demonstrated that phytoplankton diversity index $\left(\mathrm{H}^{-}\right)$at the studied sites was low and this is indication of moderate pollution. Also, the diversity to some extent increase with increase nutrients.

\section{References}

Abdel-Tawwab, M.; Abdelghany, A.E. and Ahmad, M.H. (2007). Effect of Diet Supplementation on Water Quality, Phytoplankton Community Structure, and the Growth of Nile Tilapia, Oreochromis niloticus (L.), Common Carp, Cyprinus carpio (L.), and Silver Carp, Hypophthalmichthys molitrix (V.), Polycultured in Fertilized Earthen Ponds. J. Appl. Aquacult., 19(1): 1-24.

Abdo, M.H. (2005). Physico-chemical Characteristics of Abu Za'baal Ponds, Egypt. Egypt. J. Aquat. Res., 31(2): 1- 15.

Adamovich, B. and Zhukova, H. (2014). Relationship between Chlorophyll $a$ Content and Some Phytoplankton Characteristics in Fish Ponds and Adjacent Watercourses. Hydrobiol. J., 50(5):27-34.

Affan, A.; Jewel, A.; Haque, M.; Khan, S. and Lee, J.B. (2005). Seasonal Cycle of Phytoplankton in Aquaculture Ponds in Bangladesh. Algae., 20(1):43-52.

APHA (American Public Health Association) (2005). Standard Methods for Examination of Water and Wastewater $21^{\text {st }}$ edition. Washington, D.C., USA. 
Bhuiyan, A.S.; Islam, M.T. and Sharmeen, R. (2008). Occurrence and Abundance of Some Copepods in a Fish Pond in Rajshahi, Bangladesh in Relation to the Physico-chemical Conditions. J. Biosci., 16:115-119.

Boyd C.E. (1998). Water Quality for Pond Aquaculture. Research and Development Series. International Centre for Aquaculture and Aquatic Environment, Alabama Agriculture Experiment Station, Auburn University, Alabama, USA. 37p.

Boyd, C.E. and Tucker, C.S. (1992). Water Quality and Pond Soil Analysis for Aquaculture. Alabama Agricultural Experiment Station. Auburn University, USA. 183 pp.

DE Wever, A.; Muylaert, K.; Langlet, D.; Alleman, L.; Descy, J.; Andre', L.; Cocquyt, C. and Vyverman, W. (2008). Differential response of phytoplankton to additions of nitrogen, phosphorus and iron in Lake Tanganyika. Freshw. Biol., 53:264-277.

Dytham, C. (1999). Choosing and using statistics: A Biologist's guide. Blackwell Science Ltd., London, UK.

El-Otify, A.M. (2015). Evaluation of the physicochemical and chlorophyll- $a$ conditions of a subtropical aquaculture in Lake Nasser area, Egypt. BENISEUF UNIV. J. APPL. SCI..4: 327-337.

El Sheekh, M.M.; Deyab, M.A.I.; Shaban-Dessouki, S. and Eladi, M. (2010). Phytoplankton composition as a response of water quality in El-Salam Canal Hadous Drain and Damietta Branch of River Nile Egypt. Pak. J. Biol., 42(4):2621-2633.

Ferdoushi, Z.; Haque, F.; Khan, S. and Haque, M. (2008). The Effects of two aquatic floating macrophytes (Lemna and Azolla) as biofilters of nitrogen and phosphate in fish ponds. Turk. J. Fish. Aquat. Sci., 8:253-258.

Garcia, J. J.; Correa, G. A. and Pardo-Carrasco, S. C. (2012).Phytoplankton and periphyton in ponds with Nile tilapia (Oreochromisniloticus) and bocachico (Prochilodusmagdalenae). Rev. Colomb. Cienc.Pecu., 25:603614.

Gledhill M. and Van den Berg C. (1994). The determination of complexation of iron (III) with natural organic complexing ligands in seawater using cathodic stripping voltammetry. Mar. Chem., 47: 41-54. 
Hossain, M.I.; Alam, M.M.; Alam, M.; Kamal, B. M. M. and Galib, S.M. (2013). Investigation of Phytoplankton and Physico-chemical Parameters in Nursery, Growout and Broodstock Ponds. J. Sci. Res., 5 (3): 555-571.

Hulyal S.B. and Kaliwal B.B. (2011). Seasonal Variations in Physico-Chemical Characteristics of Almatti Reservoir of Bijapur district, Karnataka State, IJEP., 1 (1):58-67

ICAR. (2011). "Handbook of Fisheries and Aquaculture". ICAR publication, New Delhi, India. Pp. 1116.

Khan, M. A. and Bhatt, G. H. (2000). Biological invasion and 'Red water' phenomenon in lake. Manasbal of Kashmir Valley, India. Poll. Res., 19: 113-117.

Lukaw, Y.S.; Kenyi, D.D. and Ladu, J.L.C. (2013). Physicochemical Characteristics and Bacillariophyceae as Indicators of Trophic Status in the Tropical Reservoir of Jebel El-Aulia, Sudan. Inter. J. Agric. Sci. Bioresour. Engin. Res., 2 (1):7-18.

Mageed, A. A. and Konsowa, A. H. (2002). Relationship between phytoplankton, zooplankton and fish culture in a freshwater fish farm. Egypt. J. Aquat. Biol. Fish., 6 (2): 183-206.

Margalef, R. (1978). Life-forms of phytoplankton as survival alternatives in an unstable environment.Oceanol.Acta., 1: 493-509.

Margalef, R. (1964). Correspondence between the classical types of lakes and structural and dynamic properties of their populations.Verh. Inter. VerienTheor. Angew .Limnol., 15: 169-175.

Mineyeva, N.M. (2004). Rastitelnye pigmenty $v$ vode volzhskikh vodokhranilishch. (Plant pigments in the water of the Volga Reservoirs.) / Ed. by V.T. Komov. Moscow, Nauka Press. 156 p. [Rus.].

Mustapha, M. K. and Omotosho, J. S. (2005).An assessment of the PhysicoChemical properties of Moro Lake, Kwara State, Nigeria. African J. Appl. Zoo. Environ. Biol., 7: 3-77.

Nassar, M.Z. and N.G. Shams El-Din. (2006). Seasonal dynamics of phytoplankton community in the bitter lakes and Temsah Lake. Egypt. J. Aquat. Res., 32 (1): 198-219. 
Niusha, A.; Jamili, S. and Abdolbaghian, S. (2014). Diversity of Macrobenthos Communities and Their Relationships with Environmental Factors in Jajroud River, Iran. Resour. \& Environ., 4(2): 95-103.

Paerl H. L; Prufert-Bebout L. E. and Guo C. (1994). Iron-stimulated $\mathrm{N}_{2}$ fixation and growth in natural and cultured populations of the planktonic marine cyanobacteria Trichodesmium spp. Appl. Environ. Microbiol., 60:1044-1047.

Patil J.V.; Ekhande, A.P. and Padate, G. S. (2013). Water quality monitoringStudy of seasonal variation of diatoms and their correlation with physicochemical parameters of Lotus Lake, Toranmal (M.S.) India. Arch. of Appl.Sci. Res. 5 (1):172-176.

Pielou E. C. (1975). "Ecological Diversity". John Wiley Press, New York, USA.

Pirzan, A.M. and Pong-Masak, P.R. (2008). Relationship between phytoplankton diversity and water quality of Bauluang Island in Takalar Regency, South Sulawesi. BIODIVERSITAS., 9(3): 217-221.

Prescott, G. W. (1970). Algae of the Western Great Lakes Area, Department of Botany and Pathology, Michigan State University East Lansing, Michigan, USA.Pp. 1000.

Primmer, I. (2010). Chlorophyll $a$ and phytoplankton survey, Otsego Lake, 2009. In $42^{\text {nd }}$ Ann. Rept. (2009). SUNY Oneonta Biol. Fld. Sta., SUNY Oneonta.

Rani, R. and Sivakumar, K. (2012). Physico-chemical Parameters and PhytoplanktRichness in Certain Ponds of Chidambaram, Cuddalore District of Tamil Nadu. Inter. J. Res. Environ. Sci. Technol., 2(2): 35-44.

Saeed, S. M. and A. M. Batran. (2014). Evaluation of water quality parameters in two different fish culture regimes. $4^{\text {th }}$ Conference of Central Laboratory for Aquaculture Research, March 2014.

Saeed, S. M. and A. Al-Nagaawy, A. M. (2013). Impact of water hyacinth (Eichhorniacrassipes) on physico-chemical properties of water, phytoplankton biomass and Nile Tilapia production in earthen ponds. $J$. Arab. Aquacul. Soci., 8(2): 249-262.

Sen, B. and Sonmez, F. (2006). A Study on the algae in fish ponds and their seasonal variations. Int. J. Sci. Technol., 1 (1): 25-33. 
Shehata, S.A. and Badr S.A. (2010). Water quality changes in River Nile Cairo, Egypt. J. Appl. Sci. Res., 6(9):1457-1465.

Shehata, S.A.; Badr S.A.; Ali G.H.; Ghazy, M.M.; Moawad, A.K. and Wahba S.Z. (2009). Assessment of Nile water quality via phytoplankton changes and toxicity bioassay test. J. Appl. Sci. Res., 5(12): 2083-2095.

Shiddamallayya, N. and Pratima, M. (2008). Impact of domestic sewage on fresh water body. J. Environ. Biol., 29: 303-308

Sipaúba -Tavares, L.H., Donadon, A.R.V. and Milan, R. N. (2011). Water quality and plankton populations in an earthen polyculture pond. Braz. $J$. Biol., 71(4):845-855.

Stickney, R. R.; Hesby, J. H. and Isbell, W. A. (1979). Growth of Tilapia nilotica in ponds with different histories of fertilization. Aquacult., 17: 189-194.

Straus N. A. (1994). Iron deprivation: physiology and gene regulation. In: Bryant DA (ed.), the Molecular Biology of Cyanobacteria. Kluwer Academic Publishers, Dordrecht, pp 731-750.

Stirling, G. and Wilsey, B. (2001).Empirical relationships between species richness, evenness, and proportional diversity. Amer. Nat., 158: 286-299.

Telesh, I.V. (2004). Plankton of the Baltic estuarine ecosystems with emphasis on Neva Estuary: a review of present knowledge and research perspectives. Mar. Pollut. Bull., 49: 206-219.

Turano, M. J.; Borski, R. J. and Daniels, H. V. (2008).Effects of cyclic feeding on compensatory growth of hybrid striped bass (Moronechrysops x M. saxtilis) food fish and water quality in production ponds. Aquacult. Res., 39 (14): 1514-1523.

Veronica, E.; Leksono, A.S.; Soemarno and Arfiati, D. (2014). Effect of water quality on phytoplankton abundance In Hampalam River and fish pond of Batanjung Village. J. Environ. Sci. Toxicol. \& Food Technol., 8(1): 1521.

Viijayakumar, S.; Rajesh, K.M.; Mridula, R.M.; Hariharan, V. (2000). Seasonal distribution and behavior of nutrients with reference to tidal rhythm in the Mulki Estuary, Southwest Coast of India. J. Mar. Biol. Ass. India., 42: 21-31. 
Yadav, P.; Yadav, V. K.; Yadav, A.K. and Khare, P.K. (2013). Physicochemical characteristics of a fresh water pond of Orai, U. P., Central India. Octa. J. Biosci., 1(2): 177-184. 


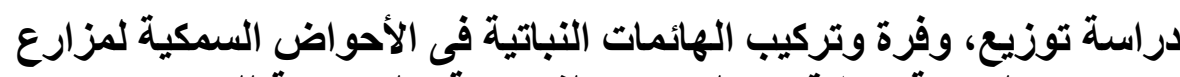

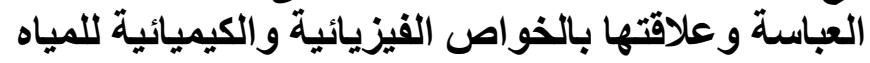

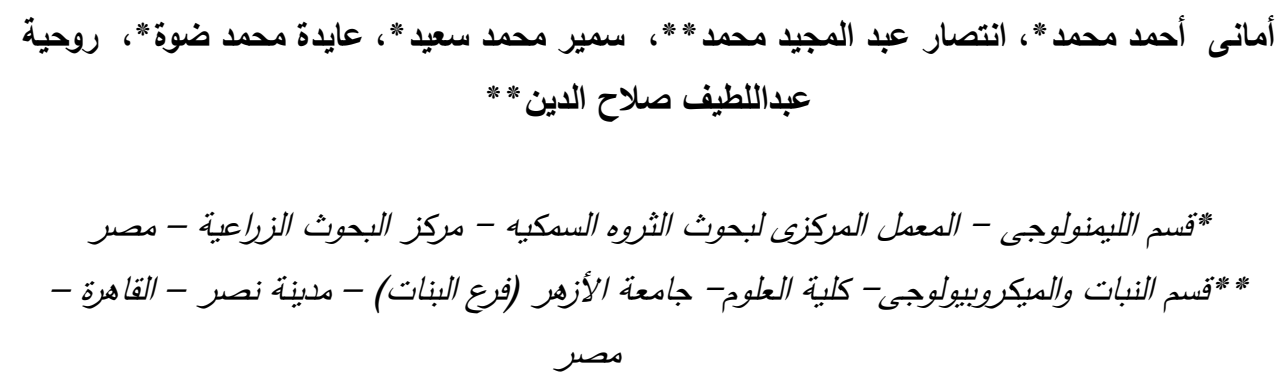

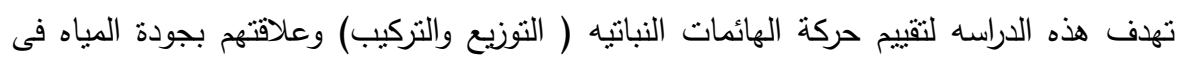

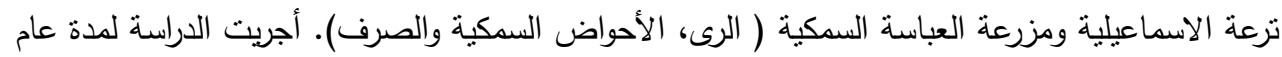
كامل ابتداء من ابريل عام 2014 وحتى مايو 2015 حيث نم قياس الخواص الفيزيائية والكيميائية

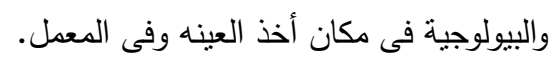

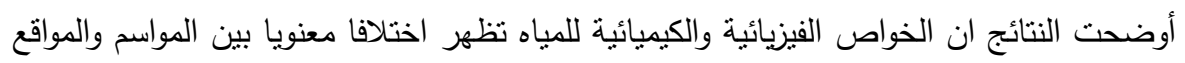

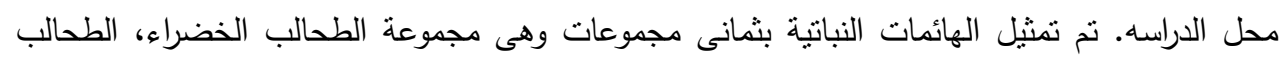

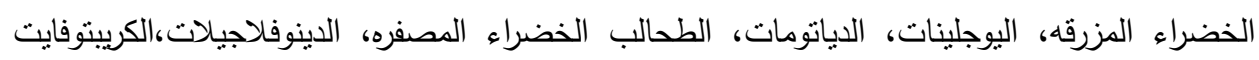

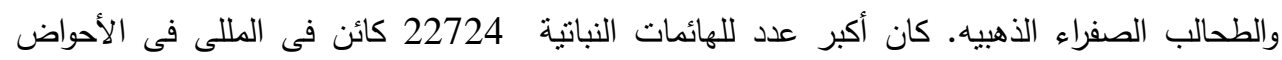

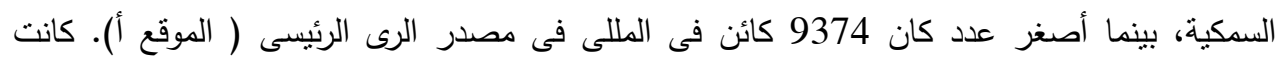

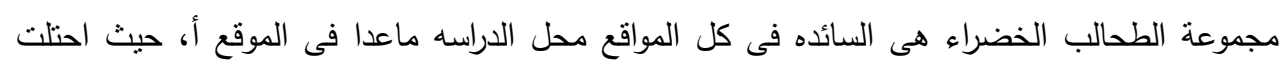

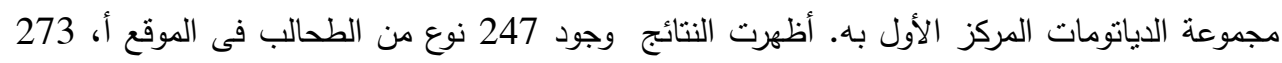
نوع فى الموقع ب، 304 نوع فى الموقع ج (الأحواض السمكيه) و 292 نوع فى الموقع د د (المصرف).

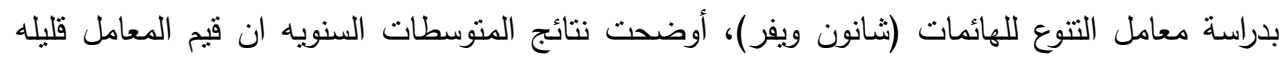
حيث انه كان اقل من 2 وهذا استدلال لوجود تلوث بدرجه منوسطه فى كل المواقع محل الدراسه. استتنج

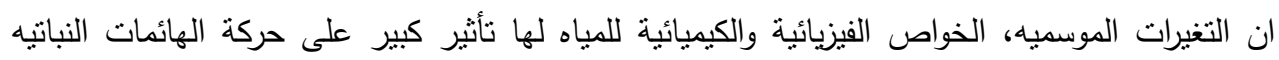
وتتوعها. 